\title{
Pesticides Removal from wastewater by Electrocoagulation Technique Using Stainless Steel (Ss-Ss) Plate Electrodes.
}

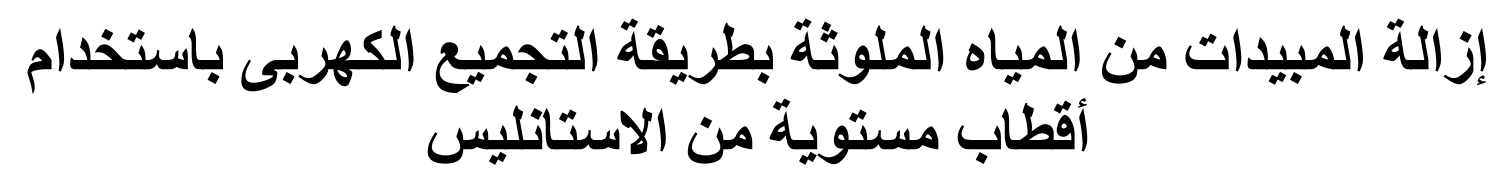

\author{
Fadali, O.A ${ }^{1}$, Ibrahim E.I ${ }^{1}$, Farrag, T.E ${ }^{2^{*}}$, and Abdelbasier A.M ${ }^{3}$. \\ 1- Chemical Engineering Department, Faculty of Engineering, El-Minia \\ University, El-Minia, Egypt \\ 2- Chemical Engineering Department, Faculty of Engineering, Post Said \\ University, Port Said, Egypt \\ 3- Alesraa Pharmaceutical Company, Badr City, Cairo, Egypt. \\ * Corresponding author: E-mail: tahafarrag70@ hotmail.com
}

\begin{abstract}
الملخص:

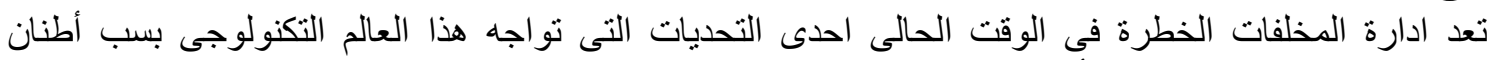

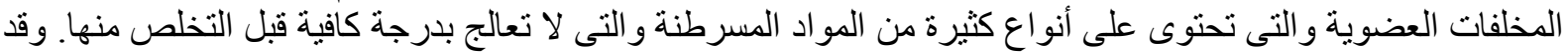

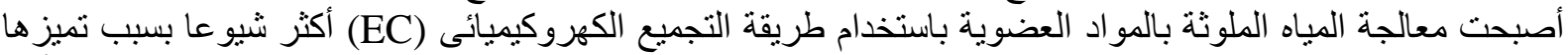

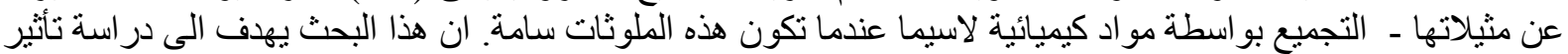

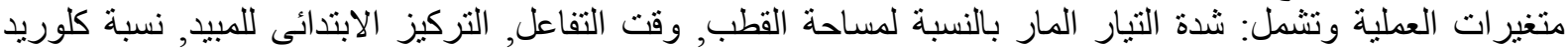

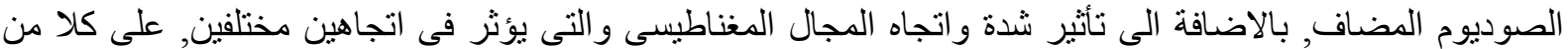

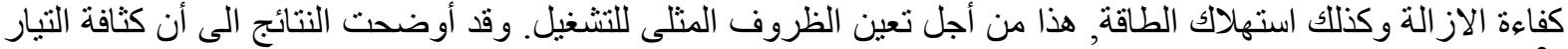

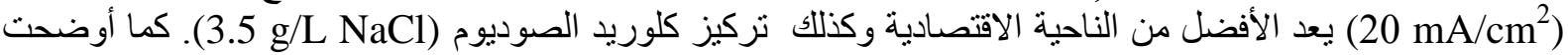

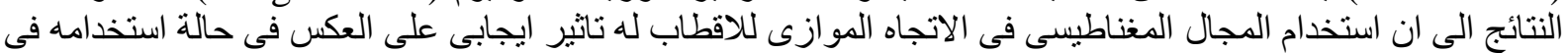
الاتجاه العمودى حيث أن نسبة از الة المبيد تصل الى 100\% خلال 45 دقيقة عند شدة مجال قيمته

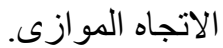

\begin{abstract}
Today hazardous waste management has become one of the most challenging tasks to this technological world because tons of organic pollutants including various carcinogens are being exposed without the sufficient treatment. Electrocoagulation (EC) due to some advantages over chemical coagulation is becoming a popular process to be used for treatment of organic pollutants especially when pollutants are toxic. The aim of this work is to investigate the effect of current density, reaction time, initial concentration, addition of sodium chloride and magnetic field intensity oriented in two different directions on both removal efficiency of methomyl and the energy consumption. Current density $20 \mathrm{~mA} / \mathrm{cm}^{2}$ was recommended from economic point of view as well as 3.5 $\mathrm{g} / \mathrm{L} \mathrm{NaCl}$ concentration. Magnetic field in parallel direction effects positive in contrary of perpendicular direction where the removal efficiency reached to $100 \%$ in $45 \mathrm{~min}$ when $0.041 \mathrm{~T}$ was applied in a parallel direction.
\end{abstract}

\section{Keywords:}

Electrocoagulation; Pesticide; Stainless steel electrodes.

\section{Introduction}

In Egypt like other many countries over the world, the agricultural activity occupies a very important place in the socio-economic domestic context which led to increase in using of pesticides. Indiscriminate use of pesticides leads to the contamination of our environment (soils, surface and ground waters). Numerous cases of pesticide residue and 
ground water contamination have been reported in the literature [1,2]. Pesticides, which indeed seem indispensable for the nutrition of mankind, take a special place among the environmentally problematic substances. Small quantities of pesticides may enter the water environment through drift, leaching and run-off from nearby applications. The contamination of water of ponds, rivers and ground water sources with various insecticides and herbicides is posing a direct threat to human health. Therefore, the removal of pesticides from water is one of the major environmental concerns these days.

The insecticide (methomyl), $\mathrm{C}_{5} \mathrm{H}_{10} \mathrm{O}_{2} \mathrm{~N}_{2} \mathrm{~S}$, is a broad spectrum insecticide which belongs to the carbamate family of pesticides. It is used for foliar treatment of vegetable specially tomato, fruit and field crops, cotton, commercial ornamentals, and in an around poultry houses and dairies. It is produced by reacting $S$-methyl- $N$-hydroxylthio acetamidate (MHTA) in methylene chloride with gaseous methyl isocyanate at $30-35{ }^{\circ} \mathrm{C}$. It has been classified by the WHO (World Health Organization), EPA (Environmental Protection Agency, USA) and EC (European Commission) as a very toxic and hazardous pesticide [3]. Methomyl pollutant causes environmental concerns because of its high solubility in water $\left(57.9 \mathrm{~g} / \mathrm{L}\right.$ at $\left.25^{\circ} \mathrm{C}\right)$. Since sorption affinity of methomyl to soils is rather low, it can easily cause contamination of both ground and surface water resources. In addition, various amounts of methomyl have been detected in surface and ground waters not only during actual insecticide application but also after a long period of use [4].

Very important issue in pesticide contamination control is preventing waste water from agricultural or industrial activities. The major sources of pollution by pesticides are waste water from agricultural industries, pesticides formulating and manufacturing plants. Waste water from those sources may contain pesticides at levels of few $\mu \mathrm{g} / \mathrm{L}$ to as high as several hundred $\mathrm{mg} / \mathrm{L}$. Suitable treatment is therefore required to prevent it, which is easier than cleaning up the environment afterwards. Several methods are available for pesticides removal such as photocatalytic degradation [5], advanced oxidation processes [6], aerobic degradation [7], nanofiltration [8], ozonation [9] and adsorption [10]. Advanced oxidation processes using hydrogen peroxides are, often ineffective because carbonate and bicarbonate ions, which are abundant in all natural water, react as strong free radical scavengers. In oxidation treatment using ozone which is a powerful oxidant, the total organic carbon removal was no more than $30 \%$. The organic pollutants are almost completely eliminated where removal of total organic carbon still remains a problem in chemical oxidation processes. The use of enzymes to detoxify wastewater failed to attract much attention due to the high cost of enzymebased systems [11]. Filtration through membranes needs another method such as oxidation reaction catalyzed by enzyme to transform the pesticide into an insoluble product, so that this method is highly expensive.

In recent years increasing attention has been directed towards the application of electrochemical methods for environmental control. It allows flexibility in design and operation and produces aesthetically superior effluents suitable for reuse. The electrochemical process is a very efficient and economic for treatment of wastewater contains toxic and nonbiodegradable organic pollutants $[12,13]$. Thus by means of electrochemical technologies, which is cost and safety effective, we can help to reduce concentrations of organic pollutants to an extent as minimum as possible and comply the environmental Egyptian law for its limits acceptable of zero COD in case of hazard organic pollutants as pesticides.

In spite of the considerable success of electrocoagulation for the treatment of 
various types of wastewater contains organic pollutants $[14,15]$, its application as a possible technique for the treatment of wastewater contains pesticides is rather scarce in the literature. The main objective of the present study, therefore, is to evaluate the removal of a pesticide (methomyl) from aqueous solutions by electrocoagulation process in a batch mode using SS electrodes. The effect of operational variables, treatment time, current density, addition of $\mathrm{NaCl}$ and initial methomyl concentration as well as effects of electromagnetic field is explored and discussed. Energy consumption was calculated under the different operating condition.

\section{Materials And Methods}

\subsection{Water Sample:}

A simulated wastewater contaminated by an insecticide, methomyl, (S-methyl N-[(methylcarbamoyl)oxy] thioacetimidate) was used for all experiments in this study. The physicochemical properties of methomyl are shown in Table 1. The methomyl was supplied by Egyptian Company for commerce and agriculture, Egypt.

Synthetic stock solutions were prepared by dissolving accurately weighed amounts methomyl in $1 \mathrm{~L}$ of distilled water. Experimental solutions of the desired concentrations were obtained by successive dilution with distilled water. At the end of each experiment, the treated solutions were filtered using Whitman No. 40 filter paper, before analysis. COD of solutions before and during the treatment process was determined and used for evaluating effective parameters. All chemicals used in the investigation were of reagent grade and were used without further purification.

Table 1. Physicochemical properties of methomyl*.

\begin{tabular}{|c|c|}
\hline Property & Parameter value \\
\hline Chemical structure & 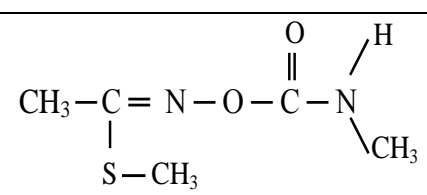 \\
\hline CAS number & $16752-77-5$ \\
\hline Chemical formula & $\mathrm{C}_{5} \mathrm{H}_{10} \mathrm{~N}_{2} \mathrm{O}_{2} \mathrm{~S}$ \\
\hline Molecular weight & $162.21 \mathrm{~g} / \mathrm{mol}$ \\
\hline Molecular volume & $179.9 \mathrm{~cm}^{3} / \mathrm{mol}$ \\
\hline Colour & White crystalline solid \\
\hline Sp.gr at $298.15 \mathrm{~K},(-)$ & 1.29 \\
\hline Solubility in water at $298.15 \mathrm{~K}$ & $58,000 \mathrm{mg} / \mathrm{L}$ \\
\hline Log octanol/water partition coefficient, $\log K_{o w}$ & 0.60 \\
\hline Log soil organic carbon-water partitioning coefficient & 2.6 \\
\hline Melting point, $\mathrm{K}$ & $351.15-316.15$ \\
\hline Vapor pressure at $298.15 \mathrm{~K}, \mathrm{~mm} \mathrm{Hg}$ & $5.4\left(10^{-6}\right)$ \\
\hline
\end{tabular}

* Resource: Hazardous Substances Data Bank (HSDB), http://toxnet.nlm.nih.gov/.

\subsection{Experimental Apparatus and Procedure:}

The batch experimental setup is schematically shown in Fig. 1. The EC unit consists of an electrochemical reactor, D.C. power supply and SS-electrodes. The electrodes consist of pieces of flat sheet (30x70x3mm) were fixed vertically and parallel to each other. The total effective electrode area was $21 \mathrm{~cm}^{2}$, and the distance between electrodes was $2 \mathrm{~cm}$. The electrodes were placed into waste water in a $350 \mathrm{ml}$ plexiglass electrolytic reactor. In a typical run, conducted at constant 
temperature $\left(25 \pm 2^{\circ} \mathrm{C}\right), 250 \mathrm{~cm}^{3}$ of the methomyl solutions with a known concentration was placed into the electrolytic cell. Magnetic field was applied on a parallel and perpendicular positions to the anode, in order to study the effect of magnetic intensity on removal of methomyl. Different intensities of magnetic field, zero, 0.016, 0.029 and 0.41 Tesla were conducted in this study.

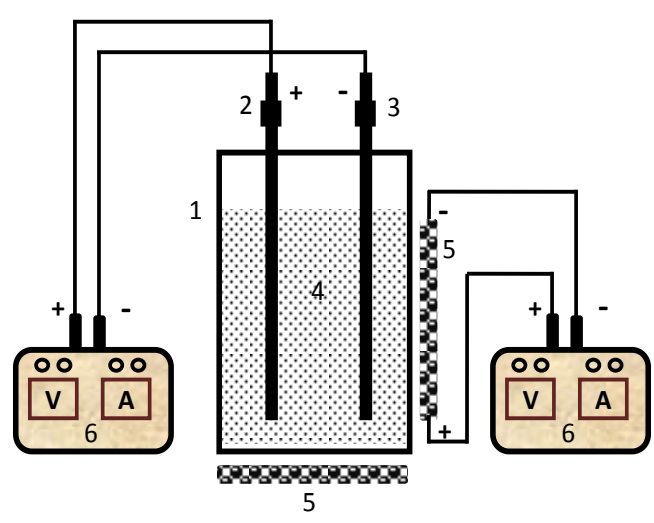

Fig. 1: Schematic diagram of experimental setup:

(1) electrochemical cell; (2) anode; (3) cathode; (4) treated solution; (5) coil to produce magnetic field (6) DC power supply.

Before each run, electrodes were washed by a dilute solution of $\mathrm{HCl}$, then by distilled water in order to remove any adhering scales or oxides and the connected impurities. The efficiency of methomyl removal, \% Removal, was calculated as:

$\%$ Removal $=\frac{C O D_{i}-C O D_{f}}{C O D_{i}} \times 00$

where $C O D_{i}$, is the initial chemical oxygen demand and its final value is $C O D_{f}$.

At the beginning of a run the methomyl solution was fed into the reactor and the $\mathrm{pH}$ was adjusted at neutral level, then the electrodes were placed into the reactor. The reaction was timed, starting when the D.C. power supply was switched on. Samples were taken at different time using a pipette, centrifuge at $3000 \mathrm{rpm}$ for
30 min then analyzed. Standard Method for Examination of Water and Wastewater was adopted for quantitative estimation of COD. The COD samples were analyzed using a Shimadzu Model UV-160 double beam spectrophotometer. The effects of current density, initial concentration, conductivity and magnetic field were investigated.

\section{Process Mechanism}

Electrocoagulation is a complex and interdependent process. A sacrificial metal anode is used to produce coagulating agent to dose the polluted water and electrolytic gases (mainly hydrogen at the cathode) are generated. Electrochemistry, coagulation and hydrodynamics form the basis of electrocoagulation [16].

The most widely used electrode materials in electrocoagulation process are aluminum and iron, sometimes steel. The electrical current causes the dissolution of metal into wastewater. The metal ions, at an appropriate $\mathrm{pH}$ value, can form wide ranges of coagulated species and metal hydroxides that destabilize and aggregate the suspended particles or precipitate and adsorb dissolved contaminants [17].

In the case of iron or mild steel electrodes, the mechanisms for the production of metal hydroxide are as [17]:

\section{Anode reactions:}

$\mathrm{Fe}-\rightarrow \mathrm{Fe}^{2+}+2 \mathrm{e}^{-}$

$2 \mathrm{Fe}^{2+}+5 \mathrm{H}_{2} \mathrm{O}+1 / 2 \mathrm{O}_{2} \rightarrow 2 \mathrm{Fe}(\mathrm{OH})_{3}$ $+4 \mathrm{H}^{+}$

$\mathrm{Fe}^{2+}+2 \mathrm{OH}^{-}-\rightarrow \mathrm{Fe}(\mathrm{OH})_{2}$

Cathode reactions:

$2 \mathrm{H}_{2} \mathrm{O}+2 \mathrm{e}^{-}-2 \mathrm{OH}^{-}+\mathrm{H}_{2}$ 


\section{The overall reactions:}

$$
\begin{aligned}
2 \mathrm{Fe}+5 \mathrm{H}_{2} \mathrm{O}+ & 1 / 2 \mathrm{O}_{2}-2 \mathrm{Fe}(\mathrm{OH})_{3} \\
& +2 \mathrm{H}_{2}
\end{aligned}
$$

$\mathrm{Fe}+2 \mathrm{H}_{2} \mathrm{O} \rightarrow \mathrm{Fe}(\mathrm{OH})_{2}+\mathrm{H}_{2}$

During electrocoagulation process, metal hydroxides formation occurs, these flocs have a large surface area, which are beneficial for a rapid adsorption of soluble organic compounds and trapping of colloidal particles. Finally, these flocs are removed easily from aqueous medium by sedimentation or flotation.

\section{Results and Discussion}

The electrocoagulation process is quite complex and may be affected by several operating parameters, such as current density (CD), pollutants concentrations, conductivity of solution, and sometimes magnetic field effect. In order to enhance the process performance, the effects of those parameters have been explored.

\subsection{Effect of Current Density}

It has been established that cell current is one of the important parameters to control the reaction rate in the electrochemical processes [18]. The current density not only determines the coagulant dosage rate, but also the bubble production rate and size. Thus, this parameter should have a significant impact on pollutants removal efficiencies. To investigate the effect of current density on the removal yield, a series of experiments were carried out on solutions with current density being varied from 5 to $50 \mathrm{~mA} / \mathrm{cm}^{2}$ where other parameters remain unchanged, $1000 \mathrm{mg} / \mathrm{L}$ methomyl concentration, $1 \mathrm{~g} / \mathrm{L}$ $\mathrm{NaCl}$ dose without magnetic effect. Fig. 2 shows that an increase in current density from 5 to $50 \mathrm{~mA} / \mathrm{cm}^{2}$ increases the percentage removal of methomyl from 57 to about $100 \%$. The highest current (50
$\mathrm{mA} / \mathrm{cm}^{2}$ ) produced the quickest removal rate, with a $82 \%$ concentration reduction occurring just after 30 min and near 100\% during $120 \mathrm{~min}$ test run. This expected behaviour is easily explained by the increase of coagulant and bubbles generation rate, resulting in a more efficient and faster removal, when the current is increased [19].

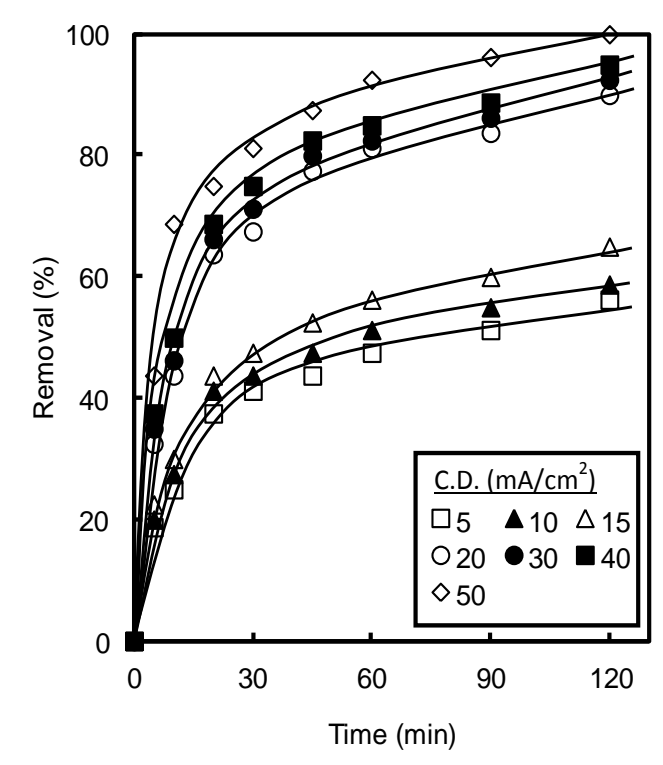

Fig. 2: Effect of current density on the removal efficiency of methomyl $\left(C_{0}=1 \mathrm{~g} / \mathrm{L}\right.$, $\mathrm{NaCl}=1 \mathrm{~g} / \mathrm{L})$.

Indeed, the amounts of metal and hydroxide ions generated at a given time, within the electrocoagulation cell are related to the current flow, using Faraday's law:

$W=\frac{I t M}{Z F}$

where $\mathrm{W}$ is the metal dissolved (g), I is the current intensity (A), $t$ is the contact time (s), $\mathrm{M}$ is the molecular weight of iron or hydroxide ion $(\mathrm{g} / \mathrm{mol}), \mathrm{z}$ is the number of electrons transferred in the reaction ( 2 for iron and 1 for hydroxide) and $\mathrm{F}$ is the Faraday's constant $(96500 \mathrm{C} / \mathrm{mol}$ of electrons). 
To assist in assessing the economic feasibility of electrocoagulation in comparison with other techniques, the energy consumption was calculated as follows [19]:

Energy consumption $(\mathrm{kWh} / \mathrm{g}$ methomyl

removed $)=\frac{V I t}{\left(C_{0}-C_{t}\right) * Q}$

Where: $\mathrm{V}$ is the cell voltage $(\mathrm{V}), \mathrm{I}$ is the cell current $(\mathrm{A}), \mathrm{t}$ is the electrolysis time (h), $\mathrm{C}_{0}$ and $\mathrm{C}_{\mathrm{t}}$ are the methomyl initial concentration and its concentration at time $\mathrm{t}$ (in $\mathrm{mg} / \mathrm{L}$ ) respectively, $\mathrm{Q}$ is the treated volume in liters.

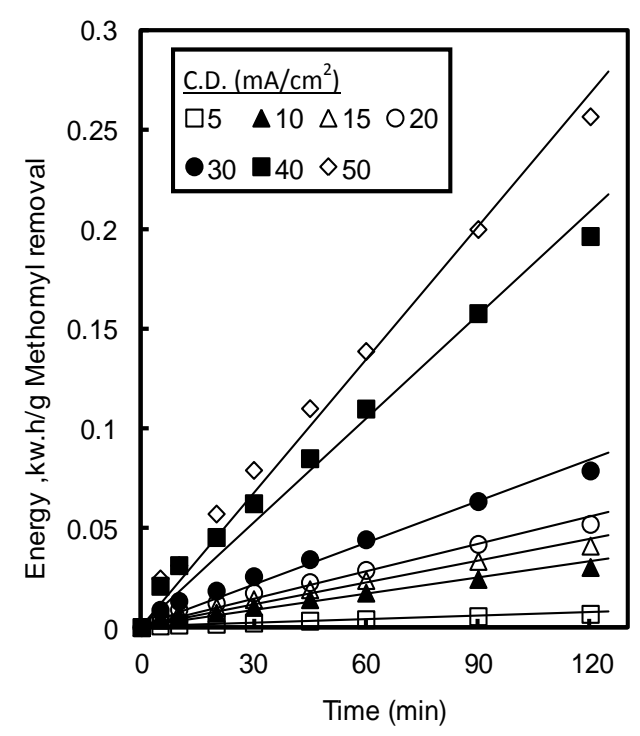

Fig. 3: Energy consumption versus time at different current densities $\left(C_{0}=1 \mathrm{~g} / \mathrm{L}, \mathrm{NaCl}=\right.$ $1 \mathrm{~g} / \mathrm{L})$.

Figure 3 shows the estimated energy consumption as a function of time for current densities 10, 20, 40 and $50 \mathrm{~mA} / \mathrm{cm}^{2}$. Exactly for all current densities, power consumption increases with time. The energy consumption is directly proportional with $\mathrm{CD}$. The highest $\mathrm{CD}$ gives best removal of methomy but with highest energy consumption. At $60 \mathrm{~min}$, the removal percent was 47.2 and 92.5 while energy consumption was 0.004 and $0.139 \mathrm{~kW} . \mathrm{h} / \mathrm{g}$ for $\mathrm{CD} 5$ and $50 \mathrm{~mA} / \mathrm{cm}^{2}$ respectively. In economic point of view, 20 $\mathrm{mA} / \mathrm{cm}^{2}$ is recommended.

\subsection{Effect of Sodium Chloride Concentration}

In order to evaluate the effect of sodium chloride concentration on the removal efficiency of methomyl from wastewater, other parameters remain constant $\left(\mathrm{C}_{0}=1000 \mathrm{mg} / \mathrm{L}, \quad C D=20\right.$ $\mathrm{mA} / \mathrm{cm}^{2}$ ) where concentration of $\mathrm{NaCl}$ was varied from 1 to $7.5 \mathrm{~g} / \mathrm{L}$, Fig. 4 .

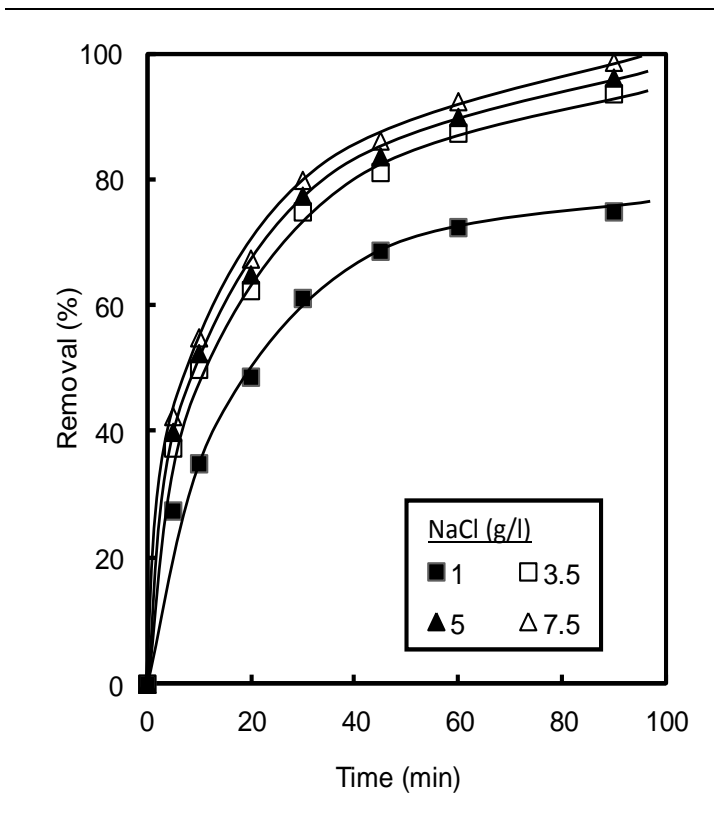

Fig. 4: Effect of $\mathrm{NaCl}$ concentration on the removal efficiency of methomyl $\left(C_{0}=1 \mathrm{~g} / \mathrm{L}, \mathrm{CD}\right.$ $=20 \mathrm{~mA} / \mathrm{cm}^{2}$ ).

Energy consumption versus time at different $\mathrm{NaCl}$ concentrations are presented in Fig. 5. As discussed before, increasing of solution conductivity will enhance the removal efficiency and the energy required for removing unit mass of pollutant will be decrease. The energy was decreased from 0.03 to $0.012 \mathrm{kw} \cdot \mathrm{h} / \mathrm{g}$ methomyl removed when the $\mathrm{NaCl}$ concentration increased from 1 to $7.5 \mathrm{~g} / \mathrm{L}$. 


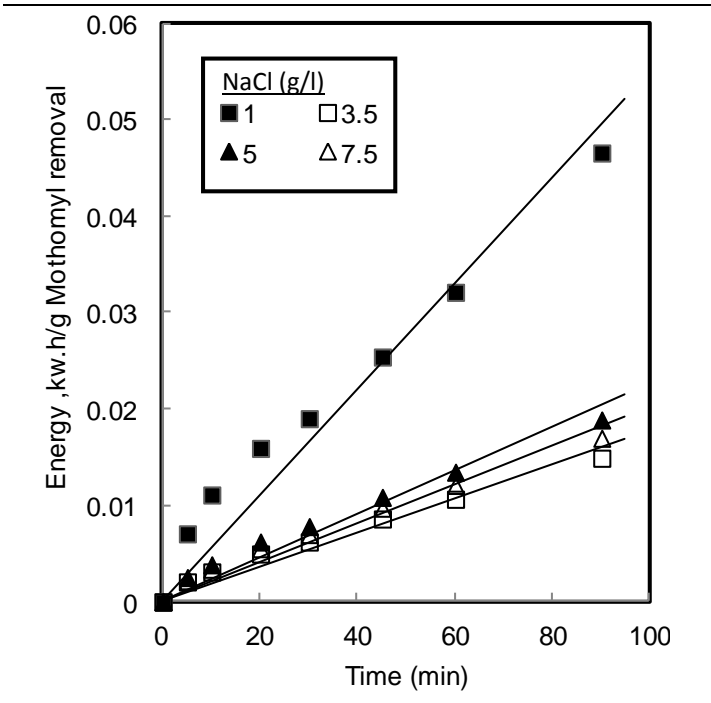

Fig. 5: Energy consumption versus time at different $\mathrm{NaCl}$ concentrations $\left(\mathrm{C}_{0}=1 \mathrm{~g} / \mathrm{L}, \mathrm{CD}\right.$ $=20 \mathrm{~mA} / \mathrm{cm}^{2}$ ).

\subsection{Effect of Initial Methomyl Concentration}

In order to examine the effect of pollutant initial concentration on the electrocoagulation performance, a set of experiments with different methomyl initial solutions ranged from 25 to 1000 $\mathrm{mg} / \mathrm{L}$. were done where other parameters remain constant at their optimum values, $\mathrm{CD}=20 \mathrm{~mA} / \mathrm{cm}^{2}$, and $\mathrm{NaCl}=3.5 \mathrm{~g} / \mathrm{L}$. The residual methomyl concentrations were measured at different times of electrolysis.

Fig. 6 shows the removal efficiency versus electrolysis time at different initial concentration. As expected, it appears that the removal rate has decreased upon increasing initial concentration. The percentage removal gradually decreases from 98 to 56.25 as the concentration increases from 25 to $1000 \mathrm{mg} / \mathrm{L}$ during 20 min. This is ascribed to the fact that at a constant current density, the same amount of metal ions passes to the solution at different methomyl concentrations.
Consequently, the formed amount of complex metal hydroxides was insufficient to coagulate the greater number of methomyl molecules at higher concentrations, which is consistent with previous studies [20]. Indeed, at high initial concentration $(1 \mathrm{~g} / \mathrm{L})$, methomyl in wastewater was reduced to admissible levels after only $20 \mathrm{~min}$.

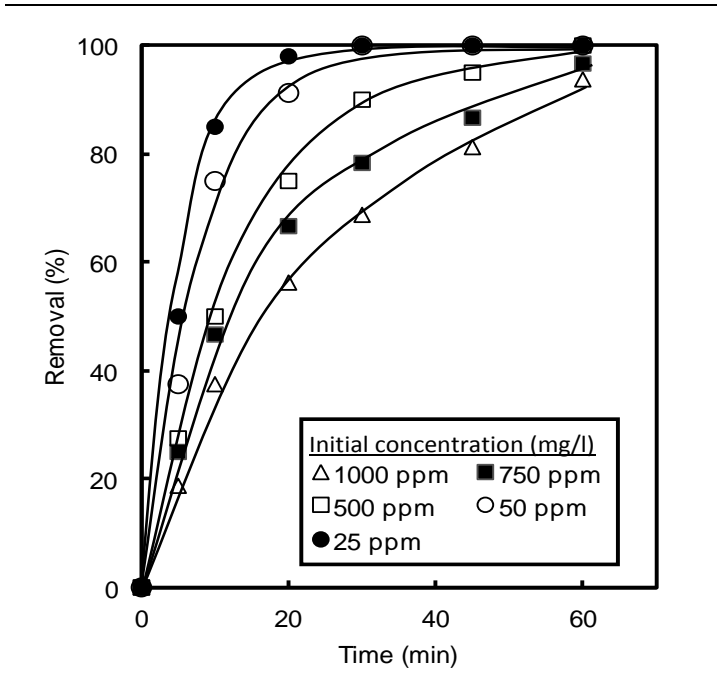

Fig. 6: Effect of methomyl initial concentration on the removal efficiency $(\mathrm{NaCl}=3.5 \mathrm{~g} / \mathrm{L}, \mathrm{CD}$ $=20 \mathrm{~mA} / \mathrm{cm}^{2}$ ).

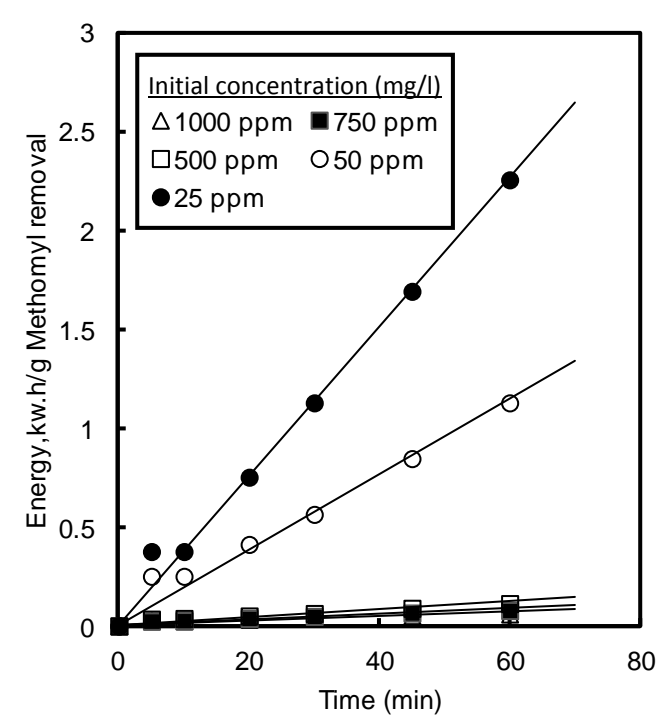

Fig. 7: Energy consumption versus time at different methomyl initial concentrations $(\mathrm{NaCl}$ $=3.5 \mathrm{~g} / \mathrm{L}, C D=20 \mathrm{~mA} / \mathrm{cm}^{2}$ ). 
Figure 7 represents the energy consumption as a function of electrolysis time for different initial methomyl concentrations. The energy consumption as $\mathrm{kW} . \mathrm{h} / \mathrm{g}$ methomyl removed has an inverse proportional with concentration, due to the chance to coagulate a greater number of methomyl molecules at higher concentrations for the same metal hydroxide in contrast at lower concentrations.

\subsection{Effect of Electromagnetic Field Intensity (EMFI)}

Other operating parameter which may be influence the performance of electrocoagulation depending on enhancement mass transfer operation is use of an electromagnetic field (EMF). To study these effect, experiments were carried out at different EMF intensity, $0.016,0.029$ and 0.041 Tesla, with two different positions, parallel and perpendicular anode direction, where other parameters are kept constant $\left(\mathrm{C}_{0}=1 \mathrm{~g} / \mathrm{L}\right.$, $\left.\mathrm{NaCl}=3.5 \mathrm{~g} / \mathrm{L}, \mathrm{CD}=20 \mathrm{~mA} / \mathrm{cm}^{2}\right)$. The results are shown in Fig 8.

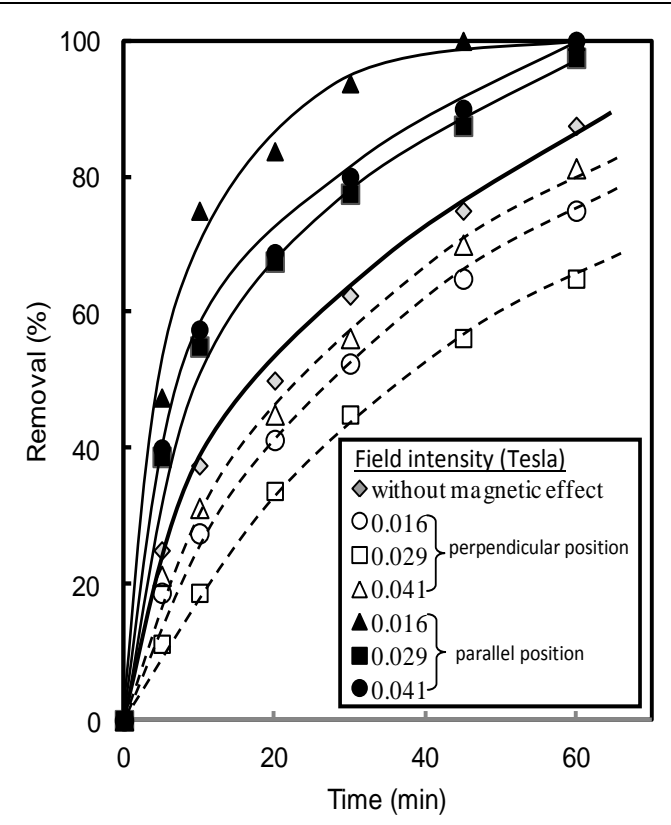

Fig. 8: Effect of EMF intensity on the removal efficiency of methomyl $\left(C_{0}=1 \mathrm{~g} / \mathrm{L}, \mathrm{NaCl}=3.5\right.$ $\left.\mathrm{g} / \mathrm{L}, \mathrm{CD}=20 \mathrm{~mA} / \mathrm{cm}^{2}\right)$.
The data plotted in Fig. 8 demonstrates that, magnetic field in parallel position effects positive in contrary in perpendicular position effects negative when compared with experiments carried in absence of magnetic field. In parallel magnetic field, the removal efficiency was increased with increasing magnetic intensity. The removal efficiency was $87.5,90$ and $100 \%$ for intensities of $0.016,0.029$ and 0.041 Tesla respectively compared with $75 \%$ when treated without magnetic field for $45 \mathrm{~min}$, and the effect is limited for high intensities. The EMF enhanced the movement of charged ions by Lorenz-force effect, where it has the same direction of ions, this movement decrease the boundary layer thickness, and enhance the mass transfer of ions in bulk solution [21]. In contrast for perpendicular position, the field direction resists the movement of charged ions in the solution and decreases its transfer. The removal efficiency was decreased from 70 to $56.25 \%$ when intensity increases from 0.016 to 0.041 Tesla and both are lower than efficiency in case of treatment without magnetic field for $45 \mathrm{~min}$.

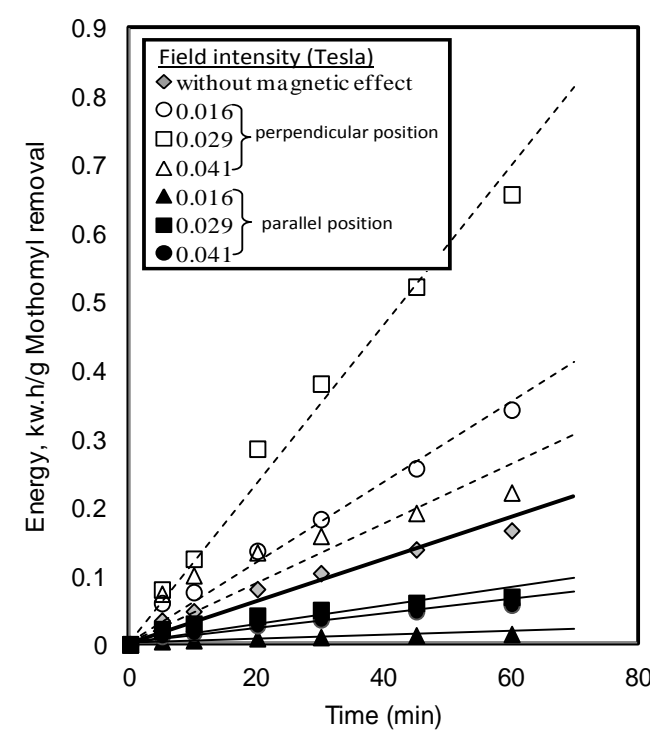

Fig. 9: Energy consumption versus time for two different positions of EMF effect $(\mathrm{NaCl}=$ $3.5 \mathrm{~g} / \mathrm{L}, \mathrm{CD}=20 \mathrm{~mA} / \mathrm{cm}^{2}$ ). 
The effect of applying EMF on energy consumption during the electrocoagulation process has been studied and presented in Fig. 9. The results illustrate that applying of EMF enhances rate of removal as well as the efficiency but increases energy consumption. The amount of metal dissolved at a given time, is highly affected by the current flow as well as intensity of EMF in parallel position in contrast with perpendicular position due to the lower of ions transfer. Thus application of EMF in electrocoagulation processes must be design in parallel position.

\section{Conclusion}

The results obtained in this study suggest an opportunity for the application of electrocoagulation technology for treatment of wastewater contaminated with methomyl. The present results have shown that:

1. Performance of methomyl removal by electrocoagulation process using SS electrodes is more efficient at CD $=20 \mathrm{~mA} / \mathrm{cm} 2, \mathrm{NaCl}=3.5 \mathrm{~g} / \mathrm{L}$.

2. The electrocoagulation can achieve percentage removal up to $100 \%$ at the optimum conditions.

3. Application of EMF in parallel position has a positive effect while its application in a perpendicular position has a negative effect due to lower mixing efficiency and ions transfer.

4. Energy consumption for electrocoagulation process was found to increase with the increase in current density as well as intensity of magnetic field and decreases with $\mathrm{NaCl}$ addition dose and initial concentration.

\section{References}

[1] Chang C., Lee S., Adsorption behavior of pesticide methomyl on activated carbon in a high gravity rotating packed bed reactor, Water research, 46, 2869-2880 (2012).
[2] Tomasevic A., Kiss E., Petrovic S., Study on the photocatalytic degradation of insecticide methomyl in water, Desalination, 262, 228-234 (2010).

[3] Bouzaida I., Ferronato C., Chovelon J.M., Rammah M. E., Herrmann J.M., Heterogeneous photocatalytic degradation of the anthraquinonic dye, Acid Blue 25 (AB25): a kinetic approach, J. Photochem. Photobiol., 168 (1-2), 23-30 (2004).

[4] Tomlin C.D.S., The Pesticide Manual, 13 Ed, BCPC, Hampshire, 697-698 (2006).

[5] Aungpradit T., Sutthivaiyakit P., Martens D., Sutthivaiyakit S., Kettrup F., Photocatalytic degradation of triazophos in aqueous titanium dioxide suspension: identification of intermediates and degradation pathways. J. Hazard. Mater., 146, 204-213 (2007).

[6] Saritha P., Aparna C., Himabindu V., Anjaneyulu Y., Comparison of various advanced oxidation processes for the degradation of 4chloro-2 nitrophenol, J. Hazard. Mater., 149, 609-614 (2007).

[7] Rajashekara H.M., Manonmani H.K., Aerobic degradation of technical hexachlorocyclohexane by a defined microbial consortium., J. Hazard. Mater., 149, 18-25 (2007).

[8] Ahmad A.L., Tan L.S., Shukor S.R.A., Dimethoate and atrazine retention from aqueous solution by nanofiltration membranes, J. Hazard. Mater., 151, 71-77 (2008).

[9] Maldonado M.I., Malato S., PérezEstrada L.A., Gernjak W., Oller I., Doménech X., Peral J., Partial degradation of five pesticides and an industrial pollutant by ozonation in a pilot-plant scale reactor, J. Hazard. Mater., 38, 363-369 (2006).

[10] Chang C.F., Chang C.Y., Hsu K.E., Lee S.C., Adsorptive removal of the pesticide methomyl using hypercrosslinked polymers, $J$. 
Hazard. Mater., 155, 295-304 (2008).

[11] Bonne P., Beerendonk E.F., Hoek V.J., Hofman J., Retention of herbicides and pesticides in relation to aging of $\mathrm{RO}$ membranes. Desalination, 132, 189-194 (2000).

[12] Palahouane B., Drouiche N., Aoudj S., Bensadok K., Cost effective electrocoagulation process for the remediation of fluoride from pretreated photovoltaic wastewater, $J$. of Industrial Engineering Chemistry, 22, 127-131 (2015).

[13] Behloul M., Grib H., Drouiche N., Abdi N., Lounici H., Mameri N., Removal of malathion pesticide from polluted solutions by electrocoagulation: modeling of experimental results using response surface methodology, Separation Science and Technology, 48(4) 664672 (2013).

[14] Bensadok, K., Benammar, S., Lapicque, F., Nezzal, G., Electrocoagulation of cutting oil emulsions using aluminum plate electrodes. J. Hazard. Mater., 152, 423-430 (2008).

[15] Cansares, P., Martinez, F., Jimenez, C., Saez, C., Rodrigo, M., Coagulation and electrocoagulation of oil-in-water emulsion. J. Hazard. Mater., 151, 44-51 (2008).

[16] Holt P K, Barton G W, A quantitative comparison between chemical dosing and electrocoagulation. Colloid Surface, 211(2/3): 233-248 (2002).

[17] Daneshvar N, Oladegaragoze A, Djafarzadeh N, Decolorization of basic dye solutions by electrocoagulation: An investigation of the effect of operational parameters. J Hazard Mater, 129, 116-122 (2006).

[18] Adhoum N, Monser L, Decolourization and removal of phenolic compounds from olive mill wastewater by electrocoagulation. Chem Eng Process, 43(10): 12811287 (2004).

[19] Khosla N.K., Venkatachalam S., Somasundaran P., Pulsed electrogeneration of bubbles for electroflotation, J. Appl. Electrochem, 21, 986-990 (1991).

[20] El-Ashtoukhy S.Z., El-Taweel Y.A., Abdelwahab O., Nassef E.M., Treatment of petrochemical wastewater containing phenolic compounds by electrocoagulation using a fixed bed electrochemical reactor, Int. J. Electrochem. Sci., 8, 1534 - 1550 (2013).

[21] Sueptitz R., Koza J., Uhlemann M., Gebert A., Schultz L., Magnetic field effect on the anodic behaviour of a ferromagnetic electrode in acidic solutions, Electrochim, Acta, 54 2229-2233 (2009). 